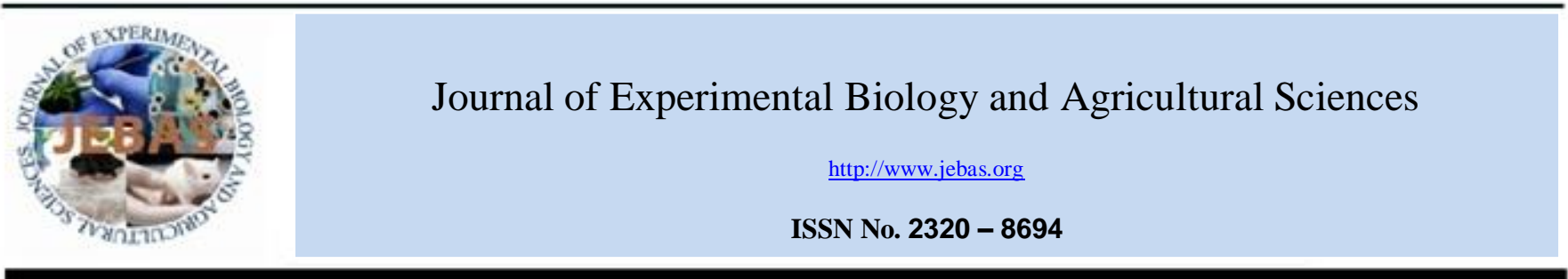

\title{
SOIL MICROBIAL POPULATION AND ENZYME ACTIVITIES UNDER ORGANIC, BIODYNAMIC AND CONVENTIONAL AGRICULTURE IN SEMI-ARID TROPICAL CONDITIONS OF CENTRAL INDIA
}

\author{
Satish Bhagwatrao Aher ${ }^{1 * \#}$, Brij Lal Lakaria ${ }^{2}$, Swami Kaleshananda ${ }^{3}$, Amar Bahadur Singh ${ }^{4}$, \\ Sivakoti Ramana ${ }^{4}$, Jyoti Kumar Thakur ${ }^{4}$, Ashish Kumar Biswas ${ }^{2}$, Pramod Jha², \\ Madhab Chandra Manna ${ }^{4}$, Dharmendra Singh Yashona ${ }^{2}$
}

\footnotetext{
${ }^{1}$ School of Environment and Disaster Management, IRDM Faculty Centre, Ramakrishna Mission Vivekananda University, Narendrapur, Kolkata 700103, INDIA

${ }^{2}$ Soil Chemistry \& Fertility Division, Indian Institute of Soil Science, Bhopal 462038, INDIA

${ }^{3}$ School of Environment and Disaster Management, Ramakrishna Mission Vivekananda University, Belur Math, Howrah 711202, INDIA

${ }^{4}$ Soil Biology Division, Indian Institute of Soil Science, Bhopal 462038, INDIA
}

Received - June 19, 2018; Revision - July 31, 2018; Accepted - September 17, 2018

Available Online - October 5, 2018

DOI: http://dx.doi.org/10.18006/2018.6(5).763.773

\section{KEYWORDS}

Alkaline phosphatase

Biodynamic

Dehydrogenase

Fluorescein diacetate

Fungi

Microbial biomass

Organic agriculture

\section{ABSTRACT}

Present field experiment was conducted at the Indian Institute of Soil Science, Bhopal, India in a clayey soil (Typic Haplusterts) under soybean (Glycine max, cv. JS 335) wheat (Triticum durum, cv. HI 8498) cropping system in a randomized block design with seven treatments in four replications to study the changes in soil fungal, bacterial and actinomycetes population; and resultant enzymatic activities in soil under organic, biodynamic and conventional agriculture management. The results of study revealed that, the soil microbial population (bacteria, fungi and actinomycetes), soil enzyme activities and soil microbial biomass carbon were found in the order of organic $>$ conventional $\geq$ biodynamic agriculture. The organic agriculture registered $27-102 \%$ and $28-111 \%$ higher enzymatic activities than conventional and biodynamic agriculture, respectively. Similarly, soil microbial biomass carbon was found $30-45 \%$ and $33-42 \%$ higher under organic agriculture management as compared to conventional and biodynamic agriculture management, respectively. No significant effect of biodynamic agriculture management on soil microbial properties was observed.
* Corresponding author

E-mail: satishbaher@yahoo.com (Satish Bhagwatrao Aher)

\#Present address: NASF Project, Soil Chemistry \& Fertility Division, Indian Institute of Soil Science, Bhopal 462038, INDIA

Peer review under responsibility of Journal of Experimental Biology and Agricultural Sciences.

Production and Hosting by Horizon Publisher India [HPI] (http://www.horizonpublisherindia.in/).

All rights reserved.
All the article published by Journal of Experimental Biology and Agricultural Sciences is licensed under a Creative Commons Attribution-NonCommercial 4.0 International License Based on a work at www.jebas.org.

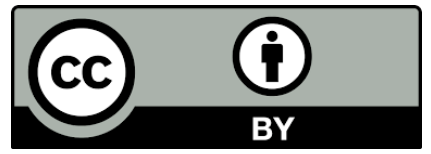




\section{Introduction}

Chemical fertilizers play an important role to meet nutrient requirement of the crop and their increased use has been an important tool in the drive for increased crop production (Fan, 1991). In the present scenario of energy crisis, the cost of fertilizers is high and inadequate (Dawson \& Hilton, 2011). Also, increase in production and consumption of mineral fertilizers seriously affects the natural environment through air, water and soil pollution (Tilman et al., 2002). The continuous and large/imbalanced quantities of mineral fertilizers have slowed down and in some cases there are indications of decline in soil productivity and production (Reganold et al., 1987; Foley et al., 2005). Reduced agricultural productivity, deteriorated soil health, escalating production costs, heavy reliance on non-renewable resources, depleting soil organic carbon, reduced microbial diversity (Zhong \& Cai, 2007), water contamination, chemical residues in food grains and health risk to the population are the main reason to think for substituting the nutrient requirement of the crops through organic inputs (Carvalho, 2006). Recent studies have highlighted the substantial contribution of organic farming towards protection and conservation of environment and food safety, quality and security (Scialabba \& Hattam, 2002; Aher et al., 2015).

Considering the above facts present study was conducted to evaluate the changes in soil microbial population (fungi, bacteria and actinomycetes), soil enzyme activities viz., dehydrogenase, alkaline phosphatase and fluorescein diacetate; and soil microbial biomass carbon under organic, conventional and biodynamic agriculture management practices in a Vertisol soil of Central India.

\section{Materials and methods}

\subsection{Study Site and Climate}

Present investigation was conducted under Network Project on Organic Farming (NPOF) at Research Farm of the Indian Institute of Soil Science, Bhopal. Geographically, the experimental site lies between $23^{\circ} 18^{\prime} \mathrm{N}$ latitude and $77^{\circ} 24^{\prime} \mathrm{E}$ longitudes. The elevation above mean sea level is $495 \mathrm{~m}$. The site falls under sub-humid tropics with an average annual rainfall of $1208 \mathrm{~mm}$ and a mean annual air temperature of $25^{\circ} \mathrm{C}$. Out of total annual rainfall, about 80 per cent is received from South-West monsoon (June to September), while the rest from North-East monsoon (October and November). Agro-ecologically, the study region lies in Vindhya plateau region (Zone No. IV) having sub-humid climate.

\subsection{Characteristics of experimental field}

The soil of experimental site is classified as Vertisol (Typic Haplustert) with smectite as the dominant clay mineral. Vertisols are churning heavy clay soils with a high proportion of swelling clays. These soils form deep wide cracks from the surface downward when they dry out, which happens in most years. The initial characteristics of the experimental soil are presented in Table 1. The soil of the experimental site is clayey in texture (Typic Haplusterts) with 25.2, 18 and 56.8 per cent of sand, silt and clay, respectively. Initially, the soil (0 to $15 \mathrm{~cm}$ depth) was medium in soil organic carbon ( $0.53 \%)$, low in available $\mathrm{N}(68.8$ $\mathrm{mg} \mathrm{kg}$ ), medium in available $\mathrm{P}\left(12.8 \mathrm{mg} \mathrm{kg}^{-1}\right)$ and high in available $\mathrm{K}\left(237 \mathrm{mg} \mathrm{kg}^{-1}\right)$. The soil was slight alkaline in reaction (pH 7.76) with $0.48 \mathrm{dS} \mathrm{m}^{-1}$ electrical conductivity.

Table 1 Initial physical and chemical properties of experimental soil $(0-15 \mathrm{~cm})$

\begin{tabular}{|cc|}
\hline Properties & Value \\
\hline Sand $(\%)$ & $25.2 \pm 2.3$ \\
\hline Clay $(\%)$ & $18.0 \pm 1.8$ \\
\hline Silt $(\%)$ & $56.8 \pm 4.2$ \\
\hline $\mathrm{pH}(1: 2)$ & $7.76 \pm 0.03$ \\
\hline $\mathrm{EC}(1: 2) \mathrm{dS} \mathrm{m}^{-1}$ & $0.48 \pm 0.01$ \\
\hline Organic carbon (\%) & $0.53 \pm 0.02$ \\
\hline Available $\mathrm{N}\left(\mathrm{mg} \mathrm{kg}^{-1}\right)$ & $68.8 \pm 9.8$ \\
\hline Available $\mathrm{P}\left(\mathrm{mg} \mathrm{kg}^{-1}\right)$ & $12.8 \pm 0.8$ \\
\hline Available $\mathrm{K}\left(\mathrm{mg} \mathrm{kg}^{-1}\right)$ & $237 \pm 12.2$ \\
\hline
\end{tabular}

\subsection{Field Experiment and Treatments}

The experiment was conducted in randomized block design with seven treatments in four replications. The experiment consisted of OM-Organic manure on nitrogen equivalent basis, BDBiodynamic Preparation (BD 500 (Cow Horn Manure) as soil application@75 $\mathrm{g} \mathrm{ha}^{-1}+B D 501$ (Cow Horn Silica) as foliar application@ $\left.2.5 \mathrm{~g} \mathrm{ha}^{-1}\right), \mathrm{OM}+\mathrm{PG}-$ Organic Manure on nitrogen equivalent basis + foliar spray of $3 \%$ Panchagavya, OM+BDOrganic Manure on nitrogen equivalent basis+ Biodynamic Preparation (BD 500 - Cow Horn Manure) as soil application @ $75 \mathrm{~g} \mathrm{ha}^{-1}+$ BD 501 (Cow Horn Silica) as foliar application @ 2.5 $\left.\mathrm{g} \mathrm{ha}^{-1}\right), \mathrm{OM}+\mathrm{PG}+\mathrm{BD}$ - Organic Manure on nitrogen equivalent basis+ Biodynamic Preparation (BD 500(Cow Horn Manure) as soil application @ $75 \mathrm{~g} \mathrm{ha}^{-1}+$ BD 501 (Cow Horn Silica) as foliar application@2.5 $\left.\mathrm{g} \mathrm{ha}^{-1}\right)+$ foliar spray of $3 \%$ Panchagavya, 
Control and RDF- Recommended dose of chemical fertilizers $\mathrm{N}: \mathrm{P}: \mathrm{K}$ through urea, single super phosphate and murate of potash, respectively (Table 2 ).

Table 2 Details of different treatments used in present study

\begin{tabular}{|ll|}
\hline Treatment & Description \\
\hline $\mathrm{OM}$ & Organic Manure* \\
\hline $\mathrm{BD}$ & Biodynamic Preparations \\
\hline $\mathrm{OM}+\mathrm{PG}$ & Organic Manure + Panchagavya \\
\hline $\mathrm{OM}+\mathrm{BD}$ & Organic Manure + Biodynamic Preparations \\
\hline $\mathrm{OM}+\mathrm{PG}+\mathrm{BD}$ & Organic Manure + Biodynamic Preparations + Panchagavya \\
\hline Control & Control \\
\hline RDF & Recommended Dose of Chemical Fertilizers \\
\hline
\end{tabular}

*For soybean crop the organic manure (OM) is cattle dung manure (CDM) and for wheat crop organic manure is cattle dung manure $(C D M)+$ vermicompost $(V C)+$ poultry manure $(P M)$ in 1:1:1 proportion on nitrogen equivalent basis.

Cattle dung manure (CDM), vermicompost (VC) and poultry manure (PM) were used as organic manure and was applied on the $\mathrm{N}$ equivalent basis with due adjustment of moisture in all the treatments involving application of organic manure. The panchagavya was prepared by mixing of cow dung, cow urine, milk, curd and ghee in 5:3:2:2:1 proportion in 3 liter of water and incubated for 10 days in a wide mouth plastic container. In addition to five products, jaggery (500 g), ripened banana fruit (12 nos.) and water of tender coconut (3 liter) were also added to improve the fermentation process. The contents were stirred daily clockwise and anticlockwise during morning and evening. The prepared panchagavya were filtered with cloth and used for foliar spray (3\%). The biodynamic preparation BD 500(Cow Horn Manure) and BD 501 (Cow Horn Silica) were commercially procured from Kurinji Organic Food (I) Pvt. Ltd., Theni - 625203, Tamil Nadu, India. The mean nutrient content of the organic inputs used in this experiment was cattle dung manure $(0.86 \% \mathrm{~N})$, $\mathrm{P}(0.44 \%)$; vermicompost (1.09\% N), P $(0.73 \%)$ and $\mathrm{K}(0.82 \%)$; poultry manure $\mathrm{N}(1.63 \%), \mathrm{P}(1.17 \%)$ and $\mathrm{K}(1.29 \%)$; panchagavya $\mathrm{N}(0.78 \%), \mathrm{P}(0.19 \%)$ and $\mathrm{K}(0.35 \%)$; Cow horn manure (BD 500) $\mathrm{N}(2.12 \%), \mathrm{P}(0.81 \%)$ and $\mathrm{K}(0.82 \%)$ whereas in cow horn silica (BD 501) no nutritional element was detected (Table 3). Cattle dung manure and cow horn manure (BD 500) was supplied as basal application before last plough. Doses of fertilizers in recommended dose of chemical fertilizer treatment were given as basal application at the time of sowing. The panchagavya (3\%) and cow horn silica (BD 501) were used as foliar spray and soil application.

Disease and pest free seeds of soybean (cv. JS-335) and wheat (cv. HI8498) were used for sowing with 45 X $5 \mathrm{~cm}$ and 22.5 X 5 $\mathrm{cm}$ spacing, respectively. The seed was treated with phosphate solubilizing micro-organisms (PSB) and Rhizobium having $10^{9}$ viable cell $\mathrm{g}^{-1}$ (Manufactured by Biofertilizer Unit of Jawaharlal Nehru Krishi Vishwa Vidyalaya (JNKVV), Jabalpur) @ $20 \mathrm{~g} \mathrm{~kg}^{-1}$ seed. The crop soybean was raised under rainfed conditions while 4 irrigations were applied to wheat crop. Neem Oil (Azadiractin 3\%; Make: Pest Control (I) Pvt. Ltd) and Hostathion (Trizophos 40 EC; Make: Bayer Crop Science Ltd.; @ 0.75 lit ha $^{-1}$ ) was used to control the pests in organic and chemical fertilizer treatments, respectively. Pheromone Traps were also used in organic plots in order to control the crop specific pest Helicoverpa armigera and Spodoptera litura of soybean. The yield of each crop was recorded at harvest on the basis of total weight of seed and grain of soybean and wheat, respectively from the experimental plot. The soybean in kharif and wheat in rabi (2011-12 and 2012-13) were grown with the selected set of treatments. In organic treatments, nutrients were applied through cattle dung manure to the soybean crop during the rainy season (July- October) and a combination of cattle dung manure + vermicompost + poultry manure (one third each) to wheat during the winter season (November-March) (Table 4). These manures were applied on the $\mathrm{N}$ equivalent basis to with due adjustment of moisture in manure (Table 3 and Table 4). The nutrients in the RDF treatment plots were supplied through chemical fertilizers.

\subsection{Analysis of organic manures for $N, P$ and $K$}

The macronutrient composition of applied manures was determined before field application. The collected sample of manures was initially air dried and further kept in oven at $65^{\circ} \mathrm{C}$ till constant weight was reached. These samples were powdered in grinder and used for determining concentration of total N, P and

Table 3 Mean nutrient composition of organics used in the experiment

\begin{tabular}{|cccccc|}
\hline Nutrient $\left(\mathrm{g} \mathrm{kg}^{-1}\right)$ & $\mathrm{CDM}$ & $\mathrm{VC}$ & $\mathrm{PM}$ & PG & BD 500 \\
\hline Nitrogen $(\mathrm{N})$ & $8.6 \pm 0.63$ & $10.9 \pm 1.79$ & $16.3 \pm 0.75$ & $7.8 \pm 0.11$ & $21.1 \pm 1.29$ \\
\hline Phosphorus $(\mathrm{P})$ & $4.4 \pm 0.11$ & $7.3 \pm 0.85$ & $11.7 \pm 0.25$ & $1.9 \pm 0.05$ & $8.1 \pm 0.16$ \\
\hline Potassium $(\mathrm{K})$ & $10.7 \pm 0.74$ & $8.2 \pm 0.60$ & $12.9 \pm 0.31$ & $3.5 \pm 0.15$ & $8.2 \pm 0.03$ \\
\hline
\end{tabular}

CDM- cattle dung manure; VC-vermicompost; PM- poultry manure; PG- panchagavya; BD 500- biodynamic preparation (cow horn manure). In BD 501 no nutritional element was detected 
Table 4 Experimental details of soybean-wheat sequence

\begin{tabular}{|lcc|}
\hline Particulars & \multicolumn{2}{c|}{ Test crops } \\
\hline Variety & Soybean & HI 8498 \\
\hline Nutrient $(\mathrm{N}: \mathrm{P}: \mathrm{K})$ dose $\left(\mathrm{kg} \mathrm{ha}^{-1}\right)$ & $30: 26.2: 16.6$ & $80: 17.5: 33.2$ \\
\hline Design & RBD & RBD \\
\hline Replications & 4 & 4 \\
\hline Plot size $\left(\mathrm{m}^{2}\right)$ & $6 \times 7$ & $6 \times 7$ \\
\hline Seed rate $\left(\mathrm{kg} \mathrm{ha}^{-1}\right)$ & 75 & 100 \\
\hline Spacing $(\mathrm{cm} \times \mathrm{cm})$ & $45 \times 5$ & $22.5 \times 5$ \\
\hline
\end{tabular}

Table 5 Composition of media used for growing actinomycetes, fungi and bacteria

\begin{tabular}{|c|c|c|c|c|c|}
\hline \multicolumn{2}{|c|}{$\begin{array}{l}\text { Kenknight's agar medium } \\
\text { (Actinomycetes) }\end{array}$} & \multicolumn{2}{|c|}{$\begin{array}{l}\text { Nutrient agar medium } \\
\text { (Bacteria) }\end{array}$} & \multicolumn{2}{|c|}{$\begin{array}{l}\text { Potato dextrose agar medium } \\
\text { (Fungi) }\end{array}$} \\
\hline Glucose & $1.0 \mathrm{~g}$ & Beef extract & $3 \mathrm{~g}$ & Potato (Peeled) & $250 \mathrm{~g}$ \\
\hline Monopotassium phosphate & $0.1 \mathrm{~g}$ & Peptone & $5 \mathrm{~g}$ & Dextrose & $20 \mathrm{~g}$ \\
\hline Potassium chloride & $0.1 \mathrm{~g}$ & Agar & $20 \mathrm{~g}$ & Agar & $20 \mathrm{~g}$ \\
\hline Magnesium sulphate & $0.1 \mathrm{~g}$ & Sucrose & $20 \mathrm{~g}$ & Distilled water & $1000 \mathrm{ml}$ \\
\hline Agar & $15.0 \mathrm{~g}$ & Distilled water & $1000 \mathrm{ml}$ & $\mathrm{pH}$ & $6.0-6.5$ \\
\hline Sodium nitrate & $0.1 \mathrm{~g}$ & $\mathrm{pH}$ & $6.8-7.2$ & & \\
\hline Distilled water & $1000 \mathrm{ml}$ & & & & \\
\hline $\mathrm{pH}$ & $7.0-7.2$ & & & & \\
\hline
\end{tabular}

K. Total nitrogen in manures was determined in microkjeldhal after digesting in concentrated sulphuric acid (Parkinsons \& Allen, 1975; Bremner \& Mulvaney, 1982). For determination of P and $\mathrm{K}$ the samples were digested in a mixture of $\mathrm{HNO}_{3}$ and $\mathrm{HClO}_{4}(9: 4)$ as suggested by Singh et al. (2005). The total P in digest was determined by Vanadomolybdate yellow colour method as outlined by Jackson (1973) whereas total K was determined using flame photometer (Chapman \& Pratt, 1961).

\subsection{Soil sampling, processing and analysis}

The soil samples were collected during both the years of study at the end of soybean-wheat crop cycle from $0-15 \mathrm{~cm}$ depth at three randomly selected spots in each replication and composite samples were prepared. The samples were air dried, gently ground, well mixed and sieved through $2 \mathrm{~mm}$ mesh and utilized for laboratory analysis for chemical and biological properties. For microbial analysis the field moist soil samples were collected and stored at $4{ }^{\circ} \mathrm{C}$ until further analysis.

Soil chemical parameters were determined by following standard methods (Jackson, 1973). The soil pH and EC were determined (1:2 soil:water suspension) on potentiometer. The available N (Subbiah \& Asija, 1956); available P (Olsen et al., 1954); exchangeable K (Hanway \& Heidel, 1952) and soil organic C (Walkley \& Black, 1934) was estimated from soil samples. The labile carbon (potassium permanganate easily oxidizable C) in soil was determined following the procedure of Blair et al. (1995) and Weil et al. (2003). Soil microbial biomass carbon from soil was determined by the fumigation-extraction method described by Jenkinson \& Powlson (1976) and later modified by Vance et al. (1987). The soil microbial enzyme activities viz. alkaline phosphatase (Tabatabai \& Bremner, 1969), soil dehydrogenase activity (Casida et al., 1964) and soil fluorescein diacetate enzyme activity (Schnurer \& Rosswall, 1982) were measured by following the standard methods. Soil microbial population viz. bacteria, fungi and actinomycetes in soil samples were determined by adopting the method suggested by Halvorson \& Ziegler (1933). The microbial population of bacteria, fungi and actinomycetes were expressed as colonies forming unit per gram soil ( $\mathrm{cfu} \mathrm{g}^{-1}$ soil). The $\mathrm{cfu}^{-1}$ of soil bacteria, fungi and actinomycetes, were determined by using the serial dilution pour plate technique using their respective media (Table 5). 
Table 6 Effect of organic farming practice on soil organic carbon and its fractions in 0-15 cm soil depth under soybean-wheat cropping system (Pooled data of 2011-12 and 2012-13)

\begin{tabular}{|c|c|c|c|c|c|}
\hline Treatment & $\mathrm{pH}$ & EC & SOC & $\mathrm{KMnO} 4-\mathrm{C}$ & SMBC \\
\hline $\mathrm{OM}$ & $7.84^{\mathrm{a}}$ & $0.20^{\mathrm{c}}$ & $7.62^{\mathrm{a}}$ & $551^{\mathrm{a}}$ & $274^{\mathrm{a}}$ \\
\hline $\mathrm{BD}$ & $8.01^{\mathrm{a}}$ & $0.26^{\mathrm{b}}$ & $6.29^{\mathrm{c}}$ & $309^{\mathrm{b}}$ & $203^{\mathrm{c}}$ \\
\hline $\mathrm{OM}+\mathrm{PG}$ & $7.94^{\mathrm{a}}$ & $0.20^{\mathrm{c}}$ & $7.82^{\mathrm{a}}$ & $533^{\mathrm{a}}$ & $288^{\mathrm{a}}$ \\
\hline $\mathrm{OM}+\mathrm{BD}$ & $7.92^{\mathrm{a}}$ & $0.21^{\mathrm{c}}$ & $7.66^{\mathrm{a}}$ & $523^{\mathrm{a}}$ & $270^{\mathrm{a}}$ \\
\hline $\mathrm{OM}+\mathrm{PG}+\mathrm{BD}$ & $7.92^{\mathrm{a}}$ & $0.20^{\mathrm{c}}$ & $7.73^{\mathrm{a}}$ & $539^{\mathrm{a}}$ & $279^{\mathrm{a}}$ \\
\hline Control & $8.02^{\mathrm{a}}$ & $0.25^{\mathrm{b}}$ & $6.34^{\mathrm{c}}$ & $304^{\mathrm{b}}$ & $200^{c}$ \\
\hline RDF & $7.96^{\mathrm{a}}$ & $0.29^{\mathrm{a}}$ & $6.74^{\mathrm{b}}$ & $319^{\mathrm{b}}$ & $235^{\mathrm{b}}$ \\
\hline
\end{tabular}

\subsection{Statistical analyses}

The primary data generated through observations and laboratory analysis during the investigation was compiled, pooled, statistically analyzed and the differences among the treatment means were tested for their significance $(P<0.05)$ as outlined by Gomez \& Gomez (1984) using Web Agri Stat Package 2.0 (WASP 2.0) developed by ICAR-Central Coastal Agricultural Research Institute, Goa, India.

\section{Results}

\subsection{Soil pH and electrical conductivity $(E C)$}

The $\mathrm{pH}$ of the soil was found neutral to slightly alkaline in nature across all the treatments (Table 6). It has been observed that the organic farming practice or application of chemical fertilizers had no marked difference on soil $\mathrm{pH}$ over the brief period of study which may be attributed to the fact that the soil $\mathrm{pH}$ is mainly affected by the parent material involved in soil formation and the climatic conditions. The electrical conductivity of soil ranged from $0.20 \mathrm{dS} \mathrm{cm}^{-1}$ to $0.29 \mathrm{dS} \mathrm{cm}^{-1}$ with highest value in treatment receiving recommended dose of chemical fertilizers (RDF). Significant decrease in electrical conductivity of $\mathrm{OM}, \mathrm{OM}+\mathrm{PG}$, $\mathrm{OM}+\mathrm{BD}$ and $\mathrm{OM}+\mathrm{PG}+\mathrm{BD}$ over other treatments was observed while these treatments were statistically at par with each other. Treatment RDF was statistically significant over all other treatments whereas BD and Control were found statistically at par. It has been observed that the treatments receiving organic manure alone or in combination showed slight but significant reduction in electrical conductivity (Table 6).

\subsection{Soil organic carbon (SOC)}

The SOC in different treatment combinations ranged from $6.29 \mathrm{~g}$ $\mathrm{kg}^{-1}$ to $7.82 \mathrm{~g} \mathrm{~kg}^{-1}$ with highest in treatment $\mathrm{OM}+\mathrm{PG}$ followed by
$\mathrm{OM}+\mathrm{PG}+\mathrm{BD}\left(7.73 \mathrm{~g} \mathrm{~kg}^{-1}\right)$. The lowest value was recorded in treatment BD. The treatment RDF was found statistically superior over $\mathrm{BD}$ and Control. The treatments receiving organic manure along with panchagavya $(\mathrm{OM}+\mathrm{PG}$ and $\mathrm{OM}+\mathrm{PG}+\mathrm{BD})$ and the treatments $\mathrm{OM}$ and $\mathrm{OM}+\mathrm{BD}$ recorded significantly higher SOC than any other treatment. These treatments were found statistically superior over RDF $\left(6.74 \mathrm{~g} \mathrm{~kg}^{-1}\right)$, BD $\left(6.29 \mathrm{~g} \mathrm{~kg}^{-1}\right)$ and Control $\left(6.34 \mathrm{~g} \mathrm{~kg}^{-1}\right)$. The treatments receiving organic manures either alone or in combinations reported 13-16\% increases in SOC over the treatment receiving recommended dose of chemical fertilizers (RDF) (Table 6).

\subsection{Potassium permanganate oxidizable carbon (Labile C)}

The $\mathrm{KMnO}_{4}-\mathrm{C}$ (Labile C) was ranged from $304 \mathrm{mg} \mathrm{kg}^{-1}$ in Control to $551 \mathrm{mg} \mathrm{kg}^{-1}$ in OM followed by OM+PG+BD (539 mg $\left.\mathrm{kg}^{-1}\right), \mathrm{OM}+\mathrm{PG}\left(533 \mathrm{mg} \mathrm{kg}^{-1}\right)$ and $\mathrm{OM}+\mathrm{BD}\left(523 \mathrm{mg} \mathrm{kg}^{-1}\right)$. The treatments receiving organic manures alone or in combination were found statistically at par with each other but found significant over Control and BD including RDF. The organic treatments viz. $\mathrm{OM}+\mathrm{PG}+\mathrm{BD}, \mathrm{OM}+\mathrm{PG}, \mathrm{OM}$ and $\mathrm{OM}+\mathrm{BD}$ increased $\mathrm{KMnO}_{4} \mathrm{C}$ by $64-73 \%$ over $\mathrm{RDF}$. No significant difference in labile $\mathrm{C}$ was found between the treatments $\mathrm{BD}$, Control and RDF (Table 6).

\subsection{Soil microbial biomass carbon (SMBC)}

The SMBC ranged from $200 \mathrm{mg} \mathrm{kg}^{-1}$ in control to $288 \mathrm{mg} \mathrm{kg}^{-1}$ in $\mathrm{OM}+\mathrm{PG}$ (Table 6). The treatment receiving biodynamic preparations (BD) was found statistically at par with Control. The treatments involving organic soil amendments i.e. $\mathrm{OM}+\mathrm{PG}+\mathrm{BD}$, $\mathrm{OM}+\mathrm{PG}, \mathrm{OM}$ and $\mathrm{OM}+\mathrm{BD}$ were noticed for significantly higher SMBC than RDF, BD and Control but were found statistically at par with each other. The treatment RDF was found statistically significant over BD and Control. The treatments involving 
Table 7 Effect of organic farming practice on fluorescein diacetate (FDA), dehydrogenase (DHA) and alkaline phosphatase (Alk-PO $\left.{ }_{4}\right)$ activities and bacteria, fungi and actinomycetes population in 0-15 cm soil depth under soybean-wheat cropping system (Pooled data of 2011-12 and 2012-13).

\begin{tabular}{|c|c|c|c|c|c|c|}
\hline Treatment & FDA & DHA & Alk- $-\mathrm{PO}_{4}$ & Bacteria & Fungi & Actinomycetes \\
\hline $\mathrm{OM}$ & $52.9^{\mathrm{a}}$ & $106.7^{\mathrm{a}}$ & $140.5^{\mathrm{a}}$ & $10.8^{\mathrm{a}}$ & $7.5^{\mathrm{a}}$ & $6.1^{\mathrm{a}}$ \\
\hline BD & $26.8^{\mathrm{b}}$ & $66.1^{\mathrm{b}}$ & $109.6^{\mathrm{b}}$ & $4.4^{\mathrm{b}}$ & $3.8^{\mathrm{b}}$ & $3.0^{\mathrm{b}}$ \\
\hline $\mathrm{OM}+\mathrm{PG}$ & $54.6^{\mathrm{a}}$ & $108.3^{\mathrm{a}}$ & $149.8^{\mathrm{a}}$ & $12.0^{\mathrm{a}}$ & $8.1^{\mathrm{a}}$ & $6.8^{\mathrm{a}}$ \\
\hline $\mathrm{OM}+\mathrm{BD}$ & $54.0^{\mathrm{a}}$ & $104.6^{\mathrm{a}}$ & $140.4^{\mathrm{a}}$ & $10.8^{\mathrm{a}}$ & $7.5^{\mathrm{a}}$ & $6.4^{\mathrm{a}}$ \\
\hline $\mathrm{OM}+\mathrm{PG}+\mathrm{BD}$ & $56.6^{\mathrm{a}}$ & $110.6^{\mathrm{a}}$ & $146.2^{\mathrm{a}}$ & $12.5^{\mathrm{a}}$ & $8.5^{\mathrm{a}}$ & $7.5^{\mathrm{a}}$ \\
\hline Control & $25.3^{\mathrm{b}}$ & $61.0^{\mathrm{b}}$ & $105.0^{\mathrm{b}}$ & $4.0^{\mathrm{b}}$ & $3.6^{\mathrm{b}}$ & $2.9^{\mathrm{b}}$ \\
\hline $\mathrm{RDF}$ & $28.0^{\mathrm{b}}$ & $64.5^{\mathrm{b}}$ & $110.9^{b}$ & $4.3^{\mathrm{b}}$ & $3.5^{\mathrm{b}}$ & $2.6^{\mathrm{b}}$ \\
\hline
\end{tabular}

applications of organic soil amendment either alone or in combinations increased SMBC by $35-44 \%$ and $15-22 \%$ over Control and RDF, respectively.

\subsection{Soil microbial population}

The microbial population of bacteria, fungi and actinomycetes during the two years ranged between $4.0 \times 10^{7}-12.5 \times 10^{7} \mathrm{cfu} \mathrm{g}^{-1}$, $3.5 \times 10^{4}-8.5 \times 10^{4} \mathrm{cfu} \mathrm{g}^{-1}$ and $2.6 \times 10^{6}-7.5 \times 10^{6} \mathrm{cfu} \mathrm{g}^{-1}$ soil, respectively (Table 7). The bacterial population was found to be the highest in treatment $\mathrm{OM}+\mathrm{PG}+\mathrm{BD}$ followed by $\mathrm{OM}+\mathrm{PG}$ $\left(12.0 \times 10^{7} \mathrm{cfu} \mathrm{g}^{-1}\right), \mathrm{OM}\left(10.8 \times 10^{7} \mathrm{cfu} \mathrm{g}^{-1}\right)$ and OM+BD $\left(10.8 \times 10^{7}\right.$ $\left.\mathrm{cfu} \mathrm{g}^{-1}\right)$. These treatments were found statistically superior over BD $\left(4.4 \times 10^{7} \mathrm{cfu} \mathrm{g}^{-1}\right), \operatorname{RDF}\left(4.3 \times 10^{7} \mathrm{cfu} \mathrm{g}^{-1}\right)$ and Control (4.0x $10^{7}$ $\left.\mathrm{cfu}^{-1}\right)$. The results revealed that the treatments $\mathrm{OM}+\mathrm{PG}+\mathrm{BD}$, $\mathrm{OM}+\mathrm{PG}, \mathrm{OM}$ and $\mathrm{OM}+\mathrm{BD}$; and treatments $\mathrm{BD}$, Control and $\mathrm{RDF}$ were statistically at par. Similar trends to that of bacterial population were observed for the population of fungi and actinomycetes in all the treatment combinations. The data in Table 7 indicated higher soil microbial population in treatments receiving organic nutrient inputs as compared to other treatments.

\subsection{Soil enzyme activities}

The soil enzyme activities viz. fluoroscien diacetate (FDA), dehydrogenase (DHA) and alkaline phosphatase $\left(\right.$ Alk- $\left.-\mathrm{PO}_{4}\right)$ are presented in Table 7. The FDA activity varied from 25.3 to 56.6 $\mu \mathrm{g}$ fluorescein $\mathrm{g}^{-1} \mathrm{~h}^{-1}$ with highest in treatment $\mathrm{OM}+\mathrm{PG}+\mathrm{BD}$. The FDA activity in treatments $\mathrm{OM}+\mathrm{PG}+\mathrm{BD}, \mathrm{OM}+\mathrm{PG}, \mathrm{OM}$ and $\mathrm{OM}+\mathrm{BD}$ were found statistically significant over other treatments viz. $\mathrm{BD}\left(26.8 \mu \mathrm{g}\right.$ fluorescein $\left.\mathrm{g}^{-1}\right)$, Control $\left(25.3 \mu \mathrm{g}\right.$ fluorescein $\left.\mathrm{g}^{-1}\right)$ and $\mathrm{RDF}\left(28.0 \mu \mathrm{g}\right.$ fluorescein $\left.\mathrm{g}^{-1}\right)$. The treatments $\mathrm{OM}+\mathrm{PG}+\mathrm{BD}$, $\mathrm{OM}+\mathrm{PG}, \mathrm{OM}$ and $\mathrm{OM}+\mathrm{BD}$ and treatments $\mathrm{BD}$, Control and $\mathrm{RDF}$ were found statistically at par (Table 7).

The DHA activity ranged between 61.0 and $110.6 \mu \mathrm{g}$ TPF $\mathrm{g}^{-1}$ day

${ }^{1}$ with lowest and highest values were observed for treatment
Control and $\mathrm{OM}+\mathrm{PG}+\mathrm{BD}$, respectively. The DHA activity in treatments $\mathrm{OM}+\mathrm{PG}+\mathrm{BD}, \mathrm{OM}+\mathrm{PG}, \mathrm{OM}$ and $\mathrm{OM}+\mathrm{BD}$ were significantly higher than the treatments $\mathrm{BD}$, Control and RDF. The treatments $\mathrm{OM}+\mathrm{PG}+\mathrm{BD}, \mathrm{OM}+\mathrm{PG}, \mathrm{OM}$ and $\mathrm{OM}+\mathrm{BD}$; and the treatments $\mathrm{BD}$, Control and RDF were found statistically at par. Like FDA and DHA activities, Alk- $\mathrm{PO}_{4}$ activity in soil also followed similar trends across the treatments. The values ranged from 105-149.8 $\mu \mathrm{g}$ PNP $\mathrm{g}^{-1} \mathrm{~h}^{-1}$ with higher value in treatment $\mathrm{OM}+\mathrm{PG}$ followed by OM+PG+BD (146.2 $\mu \mathrm{g} \mathrm{PNP} \mathrm{g}^{-1} \mathrm{~h}^{-1}$ ) (Table 7). With respect to the Alk- $\mathrm{PO}_{4}$ enzyme activity the treatments were found in the order of $\mathrm{OM}+\mathrm{PG}=\mathrm{OM}+\mathrm{PG}+\mathrm{BD}=\mathrm{OM}=$ $\mathrm{OM}+\mathrm{BD}>\mathrm{RDF}=\mathrm{BD}=$ Control. No significant changes in the enzyme activity in treatment BD were noticed during either years of study. It has been observed that, the treatments receiving organic manure alone or in combinations reported significantly higher soil enzyme activities (Table 7).

\section{Discussion}

\subsection{Soil organic carbon, labile carbon and microbial biomass}

The soil organic carbon (SOC) showed highest accumulation under the treatments receiving organic manures alone or in combination with liquid organics. Application of $\mathrm{OM}$ along with liquid organics resulted 20-23\% increase in SOC over control and $13-16 \%$ over conventional farming (Table 6). The observed increase in SOC might be due to the continuous buildup of carbon in soil under organic practice as it relies on external carbon inputs such as cattle dung manure, vermicompost and poultry manure. Besides the regular applications of different organic manures, the root biomass and left over stubbles have also contributed to the increment in carbon pools. Jha et al. (2014) observed an increment of $49.1 \%$ in total SOC with the application of FYM @ $15 \mathrm{tha}^{-1} \mathrm{Y}^{-}$ ${ }^{1}$ along with recommended dose of NPK on long term basis (38 years) over control in a Vertisol of Jabalpur under soybean-wheat sequence. Similarly, Lakaria et al. (2012a) also reported 105 and 
$71 \%$ higher TOC in long term organic farming practice over absolute control and recommended dose of NPK fertilizers, respectively under soybean-wheat cropping system. Manna et al. (2012) and Lakaria et al. (2012b) also reported increase in SOC with the application of FYM alone or in combination with recommended NPK fertilizers over absolute control and sole NPK fertilizer application. The results of this study are in close agreement with these findings. The higher $\mathrm{C}$ accumulation in the Vertisol may be attributed to their high silt+clay content which increase the C stabilization capacity (Six et al., 2002, Jha et al., 2012a).

The potassium permanganate oxidizable carbon $\left(\mathrm{KMnO}_{4}-\mathrm{C}\right)$ comprised of amino acids, simple carbohydrates, fraction of SMBC and other carbon compound and represents the labile pool of SOC (Zou et al., 2005). Labile pool of carbon is the fraction of SOC that has the most rapid turnover rates (Verma et al., 2010) and therefore, its oxidation drives the flux of carbon dioxide from soils to atmosphere. Also, the labile carbon pool is one which is readily decomposable, easily oxidizable and susceptible to microbial attack and is sensitive to management induced changes in soil organic carbon. This pool is very important as it fuels the soil food web and greatly influences the nutrient cycling for maintaining the quality of soil and its productivity (Majumder et al., 2008). In this study, the soil $\mathrm{KMnO}_{4}-\mathrm{C}$ content was ranged from $304 \mathrm{mg} \mathrm{kg}^{-1}$ to $551 \mathrm{mg} \mathrm{kg}^{-1}$. Lakaria et al. (2012b) and Jha et al. (2012b) also observed the $\mathrm{KMnO}_{4}-\mathrm{C}$ content between 463 and $621 \mathrm{mg} \mathrm{kg}^{-1}$ and 311.8 and $555.5 \mathrm{mg} \mathrm{kg}^{-1}$ under soybean-wheat rotation in a Vertisol. Further, the results showed that the continuous application organic manures significantly improved soil $\mathrm{KMnO}_{4}-\mathrm{C}$ content as compared to application of chemical fertilizers, sole biodynamic and absolute control. The organic treatments increased $\mathrm{KMnO}_{4}-\mathrm{C}$ by $72-81 \%$ and $64-73 \%$ over Control and RDF, respectively. Lakaria et al. (2012b) and Jha et al. (2012b) also reported $12 \%$ and 34\%; $12 \%$ and $99 \%$ higher $\mathrm{KMnO}_{4}-\mathrm{C}$ under organic farming than conventional farming and control, respectively. The higher $\mathrm{KMnO}_{4}-\mathrm{C}$ under the treatment receiving organic manures alone or in combination with liquid organics (panchagavya and/or biodynamic preparations) might be attributed to the continuous buildup of carbon in soil as present experiment on organic farming relies on external carbon inputs such as cattle dung manure, vermicompost and poultry manure. Besides the regular applications of different organic manures, the root biomass and left over stubbles have also contributed the possible increment. The increase in $\mathrm{KMnO} 4-\mathrm{C}$ was resulted from the growth and decomposition of organic materials. Plant roots could break down the carbon compound into labile carbon (Conteh et al., 1997). Labile carbon functions as the source of energy for the growth of soil microbes that is important for development of soil microbial population and influence the rate of organic material decomposition. Sardiana et al. (2014) also reported that the $\mathrm{KMnO}_{4}-\mathrm{C}$ under organic system was significantly higher $(49.01 \%)$ than that in conventional farming system. Our results are in close agreement with these results.

The soil microbial biomass carbon (SMBC) is considered to be the most active and highly labile fractions of SOC and incorporation of organic manures and residues substantially improves the labile pool of carbon hence their assay provides the meaningful information about its accumulation and dynamics in soil. The SMBC is considered to be an important early indicator of changes that may occur in the long term with regard to soil fertility and constitutes an important source and sink of nutrients (Moussa et al., 2007). In present investigation, the soil microbial biomass carbon in $0-15 \mathrm{~cm}$ soil depth ranged between 200 and $288 \mathrm{mg} \mathrm{kg}^{-1}$ under different treatment combinations, respectively (Table 6). Lakaria et al. (2012c) found that the SMBC was ranged from $113 \mathrm{mg} \mathrm{kg}^{-1}$ to $430.7 \mathrm{mg} \mathrm{kg}^{-1}$ under different land use whereas Jha et al. (2012b) recorded SMBC in the range of 88.9 to $430.7 \mathrm{mg} \mathrm{kg}^{-1}$ under different treatments in Vertisols. Recently Lori et al. (2017) also reported 32-84\% higher soil microbial biomass carbon under organic farming as compared to conventional farming practices. The results also showed that the SMBC was higher under the treatments receiving the organic manure either alone or in combinations with liquid manures (Table 6). The increase of SMBC in organic plots is, probably, due to the higher contents of more readily decomposable $\mathrm{C}$ fractions in the added organic manure (Rochette et al., 2006) which served as a food for microbial propagation and also due to the microbial biomass contained in the organic matter itself (Gattinger et al., 2004). The results are also in agreement with the findings of Melero et al. (2006), Tu et al. (2006), Araujo et al. (2009), Lakaria et al. (2012b), Jannoura et al. (2014) in soils under organic farming systems. According to Fliebach \& Mader (2000), over the long term, SMBC is significantly affected by the long-term organic management as well as by its intensity.

\subsection{Soil microbial population and enzyme activities}

The data on the soil microbial population (bacteria, fungi and actinomycetes) has followed a trend of natural population i.e. predominance of bacteria followed by actinomycetes and fungi. However, there were significant variations in population of soil bacteria, actinomycetes and fungi at the end of cropping cycle among different treatments combinations. The data indicated higher soil microbial population in treatments receiving organic manures compared to recommended dose of fertilizers, biodynamic application and absolute control (Table 7). Patil \& Varade (1998) observed that the application of FYM significantly enhanced the population of fungi, bacteria and actinomycetes. These results on microbial population in present study are in close agreement with the earlier observations reported by Graham \& 
Haynes (2005), Sanzano et al. (2009). The increased microbial population under organic manure application mainly attributed to the higher organic carbon especially biologically active phase of carbon which acted as source of energy for microbes proliferating in soil as reported by Rajannan \& Oblisami (1979). Similarly, the significant positive correlation among soil organic carbon and microbial population has already been explored earlier (Dick et al., 1994, Graham \& Haynes, 2005). Chang et al. (2007) also revealed that the soil microbial biomass, populations of bacteria, fungi and actinomycetes, increased significantly in compost treated soils over application of only chemical fertilizers and microbial activities showed significant linear correlations with the organic matter contents of the soils. The enhanced microbial population upon application of different sources of organic matter viz. FYM/CDM (Bulluck et al., 2002; Kannan et al., 2006), vermicompost (Parthasarathi et al., 2003), poultry manure (Nwangburuka et al., 2012), panchagavya (Xu, 2001), crop residues (Sanzano et al., 2009), biodynamics (Bougnom et al., 2012) are in close agreement with our results. Liu et al. (2017) reported significantly higher microbial population in organically managed plots as compared to the conventional practice.

Chemically enzymes are specialized proteins that act as biocatalyst either by accelerating or restricting rate of biochemical reactions without undergoing permanent change in original enzyme status. In soil, enzyme can exist intracellular (inside the cytoplasmic membranes of living cells) or extracellular (outside the cytoplasmic membrane) and involved in soil bio-geochemical processes such as organic matter decomposition, humus formation and nutrient cycling (Sinsabaugh et al., 1991). Dick et al. (1994) reported that, the activities of soil enzymes viz. alkaline phosphatase, dehydrogenase and fluorescein diacetate (FDA) are highly correlated to soil organic carbon which releases energy for micro-organisms and suggested that, their assay in soil provides a broad-spectrum indicator of soil biological health. In present study, the soil enzyme activities viz. fluoroscien diacetate (FDA), dehydrogenase (DHA) and alkaline phosphatase $\left(\right.$ Alk- $\left.-\mathrm{PO}_{4}\right)$ were significantly influenced by organic farming practices. The FDA, DHA and Alk- $\mathrm{PO}_{4}$ enzyme activities showed 89-102\%, 62-72\% and $27-35 \%$ increment under organic treatments as compared the treatment involving application of chemical fertilizers, respectively (Table 7). The increment might be attributed to the higher organic carbon content in soils of these plots. The soil enzyme activities are positively significantly correlated with TOC, active, slow and passive pools of carbon, soil respiration, microbial biomass and soil available nitrogen (Casida et al., 1964; Juma \& Tabatabai, 1977; Rajannan \& Oblisami, 1979; Klein \& Koth, 1980; Graham \& Haynes, 2005). The organic farming practices are known to increase the microbial enzyme activities in soil as reported by Marinari et al. (2006) and Fliebach et al. (2007). Results of the present investigation are in accordance with other researchers who also observed higher enzyme activities with the application of FYM (Zaller \& Koepke, 2004; Mandal et al., 2007; Okur et al., 2008; Bhattacharyya et al., 2012), vermicompost (Yadav et al., 2013), poultry manure (Yadav et al., 2013), biodynamic (Reeve et al., 2010) and panchagavya (Xu, 2001). The results from diverse soils and different crops are in conformity with the present findings (Liu et al. 2017).

\section{Conclusion}

The results revealed that, the soil microbial population (bacteria, fungi and actinomycetes), soil enzyme activities viz., dehydrogenase, alkaline phosphatase and fluorescein diacetate; and soil microbial biomass carbon were found higher under organic agriculture followed by conventional and/or biodynamic agriculture management. Similarly, soil microbial biomass carbon was found $30-45 \%$ and $33-42 \%$ higher under organic agriculture management as compared to conventional and biodynamic agriculture management, respectively. No significant effect of biodynamic agriculture management on soil microbial properties was observed. Among the different agriculture management practice examined, the organic agriculture management reflected as a viable technique in improving soil microbial properties. It is suggested that, further research is required to assess the potential of the organic agriculture towards nutrient mobilization through changes in soil microbial properties in different soils and diverse crops.

\section{Acknowledgements}

The corresponding author thankful to Swami Atmapriyananda, Vice-Chancellor, Ramakrishna Mission Vivekananda University, Belur Math, Howrah- 711202 (W.B.), INDIA, Dr. S. Ayyappan, Former Director General-ICAR \& Secretary, DARE, Govt. of India, New Delhi, Dr. A. Subba Rao, Former Director, ICARIISS, Bhopal and Dr. A. K. Patra, Director, ICAR-IISS, Bhopal for their kind permission and guidance. The financial support in the form of Junior Research Fellowship (UGC NET JRF 1906940) by University Grants Commission (UGC), New Delhi is duly acknowledged.

\section{Conflict of interest}

All the authors declare that there is no conflict of interest.

\section{References}

Aher SB, Lakaria BL, Kaleshananda S, Singh AB, Ramana S, Ramesh K, Thakur JK (2015) Effect of organic farming practices on soil and performance of soybean (Glycine max) under semi-arid tropical conditions in Central India. Journal of Applied and Natural Science 7: 67-71. 
Araújo AS, Leite LF, Santos VB, Carneiro RF (2009) Soil Microbial Activity in Conventional and Organic Agricultural Systems. Sustainability 1: 268-276.

Bhattacharyya P, Roy KS, Neogi S, Adhya TK, Rao KS, Manna MC (2012) Effects of rice straw and nitrogen fertilization on greenhouse gas emissions and carbon storage in tropical flooded soil planted with rice. Soil and Tillage Research 124: 119-130.

Blair GJ, Lefroy RDB, Lisle L (1995) Soil carbon fraction based on their degree of oxidation and development of carbon management index for agricultural system. Australian Journal of Agricultural Research 46: 1459-1466.

Bougnom B, Greber B, Franke-Whittle I, Casera C, Insam H (2012) Soil microbial dynamics in organic (biodynamic) and integrated apple orchards. Organic Agriculture 2: 1-11.

Bremner JM, Mulvaney CS (1982) A procedure for estimation of total nitrogen. In: Page AL (Ed.), Methods of soil analysis, part-2. Madison, Wisconsin, USA, Pp. 225-245.

Bulluck LR, Brosiusb M, Evanylob GK, Ristainoa JB (2002) Organic and synthetic fertility amendments influence soil microbial, physical and chemical properties on organic and conventional farms. Applied Soil Ecology 19: 147-160.

Carvalho FP (2006) Agriculture, pesticides, food security and food safety. Environmental Science and Policy 9: 685-692.

Casida LE, Klein D, Santora R (1964) Soil dehydrogenase activity. Soil Science 98: 371-378.

Chang EH, Chung RS, Tsai YH (2007) Effect of different application rates of organic fertilizer on soil enzyme activity and microbial population. Soil Science and Plant Nutrition 53: 132-140.

Chapman HD, Pratt FP (1961) Ammonium vandate-molybdate method for determination of phosphorus. In: Chapman HD, Pratt FP (Eds) Methods of analysis for soils, plants and water, $1^{\text {st }} \mathrm{Ed}$. Agriculture Division, California University, California, Pp. 184-203.

Conteh A, Blair GJ, MacLeod DA, Lefroy RDB (1997) Soil organic carbon changes in cracking clay soils under cotton production as studied by carbon fractionation. Australian Journal of Agricultural Research 48: 1049-1058.

Dawson CJ, Hilton J (2011) Fertiliser availability in a resource-limited world: Production and recycling of nitrogen and phosphorus. Food Policy 36: S14-S22.

Dick RP, Sandor JA, Eash NS (1994) Soil enzyme activities after 1500 years of terrace agriculture in the Colca Valley, Peru. Agriculture, Ecosystems and Environment 50: 123-131.
Fan S (1991) Effects of technological change and institutional reform on production growth in Chinese agriculture. American Journal of Agricultural Economics 73: 266-275.

Fliebach A, Mäder P (2000) Microbial biomass and size-density factions differ between soils of organic and conventional agricultural systems. Soil Biology and Biochemistry 32: 757-768.

Fliebach A, Oberholzer HR, Gunst L, Mader P (2007) Soil organic matter and biological soil quality indicators after 21 years of organic and conventional farming. Agriculture, Ecosystems and Environment 118: 273-284.

Foley JA, DeFries R, Asner GP, Barford C, Bonan G, Carpenter SR, Chapin FS, Coe MT, Daily GC, Gibbs HK, Helkowski JH (2005) Global consequences of land use. Science 309: 570-574.

Gattinger A, Bausenwein U, Bruns C (2004) Microbial biomass and activity in composts of different composition and age. Journal of Plant Nutrition and Soil Science 167: 556-561.

Gomez KA, Gomez A (1984) Statistical Procedures for Agricultural Research ( $2^{\text {nd }}$ edition), John Willey and Sons, New York, 1-680.

Graham MH, Haynes RJ (2005) Organic matter accumulation and fertilizer-induced acidification interact to affect soil microbial and enzyme activity on a long-term sugarcane management experiment. Biology and Fertility of Soils 41:249-256.

Halvorson HO, Ziegler NR (1933) Application of statistics to problems in bacteriology. I- A means of determining bacterial population by the dilution method. Journal of Bacteriology 25: 101121.

Hanway JJ, Heidel H (1952) Soil analysis methods as used in Iowa State College Soil Testing Laboratory. Iowa State College of Agriculture, USA, Bulletin 57: 1-13.

Jackson ML (1973) Soil Chemical Analysis. Prentice Hall Pvt. Ltd., New Delhi, India.

Jannoura R, Joergensen R, Bruns C (2014) Organic fertilizer effects on growth, crop yield, and soil microbial biomass indices in sole and intercropped peas and oats under organic farming conditions. European Journal of Agronomy 52: 259-270.

Jenkinson DS, Powlson DS (1976) The effects of biocidal treatment on metabolism in soil. V. A method for measuring soil biomass. Soil Biology and Biochemistry 8: 209-213.

Jha P, De A, Lakaria BL, Biswas AK, Singh M, Reddy KS, Subba Rao A (2012b) Soil carbon pools, mineralization and fluxes associated with land use change in Vertisols of central India. National Academy Science Letters 35: 475-483. 
Jha P, Garg N, Lakaria BL, Biswas AK, Subba Rao A (2012a) Soil and residue carbon mineralization as affected by soil aggregate size. Soil and Tillage Research 121: 57-62.

Jha P, Lakaria BL, Biswas AK, Saha R, Mahapatra P, Agrawal BK, Sahi DK, Wanjari RH, Lal R, Singh M, Subba Rao A (2014) Effects of carbon input on soil carbon stability and nitrogen dynamics. Agriculture, Ecosystems and Environment 189: 36-42.

Juma NG, Tabatabai MA (1977) Effects of trace elements on phosphatase activity in soils. Soil Science Society of America Journal 41: 343-346.

Kannan P, Saravanan A, Balaji T (2006) Organic farming on tomato yield and quality. Crop Research 32: 196-200.

Klein TM, Koths JS (1980) Urease, protease, and phosphatase in soil continuously cropped to corn by conventional or no-tillage methods. Soil Biology and Biochemistry 12: 293-294.

Lakaria BL, Patne MK, Jha P, Biswas AK (2012b) Soil Organic Carbon Pools and Indices under Different Land Use Systems in Vertisols of Central India. Journal of the Indian Society of Soil Science 60: 125-131.

Lakaria BL, Singh M, Reddy KS, Biswas AK, Jha P, Choudhary RS, Singh AB, Rao AS (2012a) Carbon addition and storage under integrated nutrient management in soybean-wheat cropping sequence in a Vertisol of central India. National Academy of Science Letters 35: 131-137.

Lakaria BL, Mukherjee A, Jha P, Biswas AK (2012c) Soil Carbon Mineralization as Affected by Land Use Systems and Water Regimes. Journal of the Indian Society of Soil Science 60: 71-73.

Liu Z, Rong Q, Zhou W, Liang G (2017) Effects of inorganic and organic amendment on soil chemical properties, enzyme activities, microbial community and soil quality in yellow clayey soil. PLoS ONE 12: 1-20

Lori M, Symnaczik S, Mäder P, De Deyn G, Gattinger A (2017) Organic farming enhances soil microbial abundance and activity-A meta-analysis and meta-regression. PLoS ONE 12: 1-25.

Majumder B, Mandal B, Bandyopadhyay PK, Gangopadhyay A, Mani PK, Kundu AL, Mazumdar D (2008) Organic amendments influence soil organic carbon pools and rice-wheat productivity. Soil science society of America journal 72: 775-785.

Mandal A, Patra AK, Singh D, Swarup A, Masto RE (2007) Effect of long term application of manure and fertilizer on biological activities in soil during crop development stages. Bioresource Technology 98: 3585-3592.
Manna MC, Sahu A, Subba Rao A (2012) Impact of long-term fertilizers and manure application on C-sequestration efficiency under different cropping systems. Indian Journal of Soil Conservation 40: 70-77.

Marinari S, Mancinelli R, Campiglia E, Grego S (2006) Chemical and biological indicators of soil quality in organic and conventional farming systems in Italy. Ecological Indicators 6: 701-711.

Melero S, Porras JCR, Herencia JF, Madejon E (2006) Chemical and biochemical properties in a silty loam soil under conventional and organic management. Soil and Tillage Research 90: 162-170.

Moussa AS, Rensburg LV, Kellner K, Bationo A (2007) Soil Microbial biomass in semi-arid communal sandy rangelands in the western Bophirima district, South Africa. Applied Ecology and Environmental Research 5: 43-56.

Nwangburuka CC, Olawuyi OJ, Oyekale K, Ogunwenmo KO, Denton OA, Nwanko E (2012) Growth and yield response of Corchorus olitorius in the treatment of Arbuscular mychorrhizae (AM), Poultry manure (PM), Combination of AM-PM and inorganic Fertilizer (NPK). Advances in Applied Science Research 3: 1466-1471.

Okur N, Kayikcioglu HH, Okur B, Delibacak S (2008) Organic amendment based on tobacco waste compost and farmyard manure: Influence on soil biological properties and butter-head lettuce yield. Turkish Journal of Agriculture and Forestry 32: 91-99.

Olsen SP, Coles CV, Wcrtanabe FS, Dean LA (1954) Estimation of available phosphorus in soil by extraction with sodium bicarbonate. USDA Circular, 939.

Parkinson JA, Allen SE (1975) A wet digestion for determination of nitrogen and other mineral nutrients in biological material. Communications in Soil Science and Plant Analysis 6:1-11.

Parthasarathi K, Balamurugan M, Ranganathan LS (2003) Influence of vermicompost on the physico-chemical and biological properties in different types of soil along with yield and quality of pulse cropblackgram. Journal of Sustainable Agriculture 23: 51-58.

Patil RB, Varade PA (1998) Microbial population in rhizosphere as influenced by high input rates of fertilizer application to sorghumwheat on a Vertisol. Journal of the Indian Society of Soil Science 46: 223-227.

Rajannan G, Oblisami G (1979) Effect of paper factory effluents on soil and crop plants. Indian Journal of Environmental Health 21: 120-130.

Reeve JR, Carpenter-Boggs L, Reganold JP, York AL, Brinton WF (2010) Influence of biodynamic preparations on compost 
development and resultant compost extracts on wheat seedling growth. Bioresource Technology 101: 5658-5666.

Reganold JP, Elliott LF, Unger YL (1987) Long-term effects of organic and conventional farming on soil erosion. Nature 330: 370-372.

Rochette P, Angers DA, Chantigny MH, Gagnon B, Bertrand N (2006) Insitu mineralization of dairy cattle manures as determined using soil surface carbon dioxide fluxes. Soil Science Society of America Journal 70: 744-752.

Sanzano GA, Sosa FA, Hernandez CF, Morandini M, Rojas Quinteros H, Romeroy JI, Digonzelli PA (2009) Evaluacion de la erosion hidrica en cana de azucar cony sin cobertura de maloja. Advance Agroind 30: 16-18.

Sardiana K, Adnyana M, Manuaba P, Agung MS (2014) Soil Organic Carbon, Labile Carbon and Organic Carbon Storage under Organic and Conventional Systems of Chinese Cabbage in Baturiti, Bali Indonesia. Journal of Biology, Agriculture and Healthcare 4: 63-71.

Schnurer J, Rosswall T (1982) Fluorescein diacetate hydrolysis as a measure of total microbial activity in soil and litter. Applied Environmental Microbiology 43: 1256-1261.

Scialabba N, Hattam C (2002) Organic agriculture, environment and food security (No. 4). Food \& Agriculture Organization.

Singh D, Chhonkar PK, Dwivedi BS (2005) Manual on Soil, Plant and Water Analysis, Westville Publishing House, New Delhi, India. 1-199.

Sinsabaugh RL, Antibus RK, Linkins AE (1991) An enzymic approach to the analysis of microbial activity during plant litter decomposition. Agriculture, Ecosystems and Environment 34: 43-54.

Six J, Conant RT, Paul EA, Pautain K (2002) Stabilization mechanisms of soil organic matter: Implications for C-saturation of soils. Plant and Soil 241: 155-176.

Subbiah BV, Asija GL (1956) A rapid procedure for the determination of available nitrogen in soils. Current Science 25: 259-260.

Tabatabai MA, Bremner JM (1969) Use of p-nitro-phenyl phosphatase for assay of soil phosphatase activity. Soil Biology and Biochemistry 1: 301-307.

Tilman D, Cassman KG, Matson PA, Naylor R, Polasky S (2002)
Agricultural sustainability and intensive production practices. Nature 418: 671-677.

Tu C, Louws FJ, Creamer NG, Mueller JP, Brownie C, Fager K, Bell M, Hu S (2006) Responses of soil microbial biomass and $\mathrm{N}$ availability to transition strategies from conventional to organic farming systems. Agriculture, Ecosystems and Environment 113: 206-215.

Vance ED, Brookes PC, Jenkinson DS (1987) Microbial biomass measurements in forest soils: The use of the chloroform fumigation incubation method in strongly acid soils. Soil Biology and Biochemistry 19: 697-702.

Verma BC, Datta SP, Rattan RK, Singh AK (2010) Monitoring changes in soil organic carbon pool, nitrogen, phosphorus, and sulphur under different agricultural management practices in the tropics. Environmental Monitoring and Assessment 171: 579-593.

Walkley A, Black IA (1934) Estimation of soil organic carbon by chromic acid titration method. Soil Science 37: 29-38.

Weil RR, Islam KR, Stine MA, Gruver JBE, Susan SL (2003) Estimating active carbon for soil quality assessment: A simplified method for laboratory and field use. American Journal of Alternative Agriculture 18: 3-17.

Xu HL (2001) Effects of a microbial inoculant and organic fertilizers on the growth, photosynthesis and yield of sweet corn. Journal of Crop Production 3: 183-214.

Yadav SK, Babu S, Singh Y, Yadav MK, Yadav GS, Pal S, Singh R, Singh K (2013) Effect of organic nutrient sources on yield, nutrient uptake and soil biological properties of rice (Oryza sativa)-based cropping sequence. Indian Journal of Agronomy 58: 271-276.

Zaller JG, Koepke U (2004) Effects of traditional and biodynamic farmyard manure amendment on yields, soil chemical, biochemical and biological properties in a long-term field experiment. Biology and Fertility of Soils 40: 222-229.

Zhong WH, Cai ZC (2007) Long-term effects of inorganic fertilizers on microbial biomass and community functional diversity in a paddy soil derived from quaternary red clay. Applied Soil Ecology 36: 84-91.

Zou XM, Ruan HH, Fu Y, Yang XD, Sha LQ (2005) Estimating soil labile organic carbon and potential turnover rates using a sequential fumigation incubation procedure. Soil Biology and Biochemistry 37: 1923-1928. 